DNA probes

\section{Type culture a source of gain}

Washington

THE role of the American Type Culture Collection (ATCC) as a repository of materials for basic biological rsearch is being threatened, researchers say, by commercial exploitation of cell lines deposited there. At least one molecular biologist has refused to send any more of his samples to the collection after a commercial company obtained an oncogene he had deposited and, without his knowledge, began marketing to researchers DNA probes derived from it.

ATCC, a non-profit organization, makes cell lines and other materials in its collection available to any qualified researcher who requests them, charging a nominal fee to cover its costs. Although primarily a service to basic researchers, the collection has played an increasingly important role in facilitating the patenting of recombinant DNA products and processes.

As a general rule, the Patent Office requires applicants to deposit novel cell lines or plasmids in a collection such as ATCC to satisfy the public disclosure requirements of patents - the traditional written descriptions are often insufficient to allow someone else to reproduce the invention, a fundamental requirement of patent law. In order to satisfy the legal requirements, no restrictions on the distribution of deposited materials can be imposed.

But that totally unrestricted distribution is upsetting some basic researchers. Tom Curran, a molecular biologist at Hoffmann-La Roche, recently deposited a cell line containing the fos oncogene, which he had isolated when he was a graduate student at the Imperial Cancer Research Fund Laboratories in London, in collaboration with Inder Verma of the Salk Institute.

Curran says he was subsequently "shocked and distressed" to discover an advertisement in Nature from Oncor Inc. for DNA probes for a variety of oncogenes, including fos. Curran says Oncor did not even inform him that it had obtained the sample from ATCC or that it was planning to market his product. He says his primary objection is that Oncor is making a profit by selling to basic researchers a product developed by basic research in which the company had no part. Curran says he deposited the oncogene with ATCC so that it would be "freely available to the scientific community".

Some research groups, apparently concerned about the uncontrolled commercial exploitation of cell lines placed in the public domain through ATCC or otherwise, have taken to distributing samples themselves to other basic researchers and requiring a signed agreement that those receiving them will not pass them on to a third party or exploit them commercially without permission. Although there is some dispute over the enforceability of such agreements at law, in at least one well-publicized case, that of David Golde's KG-1 cell line, the originators of the cell line won a sizeable out-ofcourt settlement from a company that had obtained and was using the material without their permission (see Nature 301, 6 ; 1983).

Bobbie Brandon of ATCC says that the collection may have to reconsider its policies on free distribution, but that it would not want to be in the position to enforce restrictions against transfers or commercial development. And, although she sympathizes with Curran's complaints, she says Curran had signed a statement agreeing that ATCC could make the oncogene available to anyone requesting it. Brandon says that ATCC distributes about 1,000 oncogene samples each year at a cost of $\$ 64$ to commercial organizations and $\$ 44$ to non-profit groups.

Steven Turner, founder and chief executive officer of Oncor, says he sees nothing wrong with the service that his company is providing and that his com-

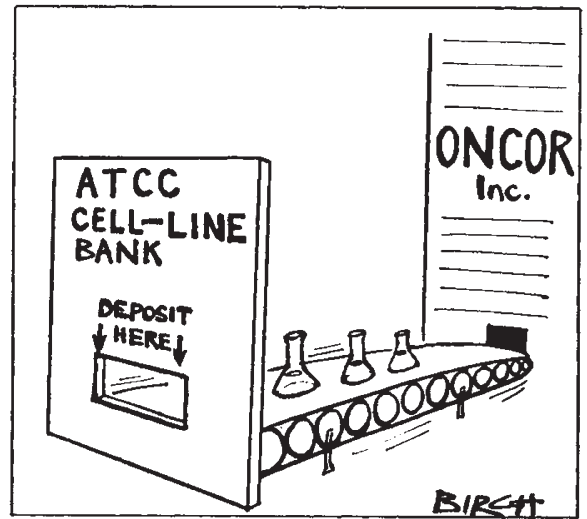

pany's contribution is by no means trivial, as Curran suggests. "We're not just taking the ATCC strain and dropping it into tin cans and selling it", he says. Turner adds that the customers for the products are not basic molecular biologists, but rather clinical researchers who do not have the means to develop the probes themselves from the material available from ATCC. And he says that strains deposited in ATCC are in fact not very attractive for commercial development because they are in the public domain: "I have no protection with what I do with that strain".

Turner, who was the founder of Bethesda Research Laboratories before founding Oncor two years ago, says, "I long ago got used to the hypocrisy of academics saying that their activities are on a higher moral plane than business"'. While academic researchers refuse to sell their cell lines, they nevertheless demand a quid pro $q u o$, such as demanding that the recipients "stick their names on your papers for the next five years". "I've never seen exploitation as I've seen it performed in academic labs."' Stephen Budiansky ๑) 1985 Nature Publishing Group
Sakharov

\section{Birthday award from US centre \\ Washington}

THE Andrei Sakharov Institute in Washington, founded five years ago to honour the Soviet academician and human rights campaigner, this year added a new feature to the now-traditional Sakharov birthday celebrations - an annual prize for science. The first recipient is Dr Aleksandr Esenin-Volpin, a mathematical logician, for many years a human rights campaigner and a victim of psychiatric repression in the Soviet Union, before he was "persuaded" to emigrate in 1972.

The prize this year is modest, a mere $\$ 5,000$, and the decision to establish it was taken only two weeks before the event. Vladimir Bukovskii, himself a former human rights campaigner and psychiatric victim, said in announcing the award that the funds were largely collected from Russian emigres in the United States, many of whom are not well-off. But in view of the number and distinction of the universities and institutions from which the "advisory board" of the Sakharov Institute is drawn, and the recent introduction of a congressional bill to grant it a federal charter, there is every hope that a more substantial sum may be available next year.

The prize is not the institute's first educational venture. In addition to its Center for Democracy, which aims at propagating Sakharov's ideas on peace and democracy and publishing in English the works of authors unable to express themselves freely in their own countries, it also maintains an education and research section, which has been adopted as the Washington Campus of Long Island University. This has two major projects in hand, the improvement of the quantity of mathematics and science education in the United States (including the establishment of a National School for Science and Mathematics for Gifted Students) and the upgrading of the quality of Soviet and East European studies.

The announcement of the new prize added an optimistic note to last week's Sakharov "birthday" conference (held a few days before the actual date, 21 May), which otherwise concentrated on current progress (or the lack of it) in international acceptance of Sakharov's views on peace, arms control and human rights.

Inevitably, the issue was raised of plans to renew contacts between the US National Academy of Sciences and the Academy of Sciences of the USSR (see Nature 16 May, p. 169). Since the National Academy broke off relations with the Soviet Academy in protest at Sakharov's internal exile to Gor'kii, it is not surprising that those gathered to honour him felt that there should be no new approach to the Soviets while Sakharov and his wife remain in exile.

Vera Rich 